ISBN: 2338-8021; E-ISSN: 2338-8269

\title{
PARTISIPASI PETANI DALAM PEMANFAATAN TEKNOLOGI INFORMASI PADA PROGRAM AGROPOLITAN BELIMBING DI BOJONEGORO
}

\section{(Farmer's Participation in Using Information Technology on Starfruit Agropolitan Program in Bojonegoro)}

\author{
Surya Kinanti ${ }^{1)}$ dan Siti Amanah ${ }^{1)}$ \\ ${ }^{1)}$ Departemen Sains Komunikasi dan Pengembangan Masyarakat, Fakultas Ekologi Manusia, Institut \\ Pertanian Bogor, Darmaga Bogor 16680, Indonesia \\ Email: suryakinanti10@gmail.com; siti_amanah@apps.ipb.ac.id
}

\begin{abstract}
Information and Communication Technology (ICT) can be utilised to support agribusiness for farmers. Agropolitan starfruit program in Bojonegoro provides ICT for farmers to be used in strengthening their starfruit agribusiness. The research aims were to analyze farmer's participation in the utilise of ICT. The research site was in Ngringinrejo Starfruit Village, Kalitidu Sub District, Bojonegoro District, East Java. A number of 50 farmers were randomly selected as sample respondents from 104 farmers. The research results showed that the farmers have not intensively used the ICT. This relates to the limited training and facilitation about ICT for farmers. There is a significant positive correlation between level of farmer's participation and the use of information technology to support the starfruit agribusiness. Training on ICT for farming business followed by appropriate facilitation need to be done to strengthen farmers knowledge and skills in ICT.
\end{abstract}

Keywords: support agribusiness, limited training, limited facilitation

\begin{abstract}
ABSTRAK
Teknologi informasi dan komunikasi (TIK) merupakan salah satu aspek untuk mendukung agribisnis untuk petani. Program Agropolitan belimbing di Bojonegoro menyediakan fasilitas TIK bagi petani untuk mendukung usaha. Penelitian bertujuan menganalisis tingkat partisipasi petani dalam pemanfaatan TIK. Penelitian dengan metode survei ini dilaksanakan di Desa Ngringinrejo, Kecamatan Kalitidu, Bojonegoro, Jawa Timur. Sebanyak 50 petani peserta program dipilih secara acak dari 104 petani. Hasil penelitian memperlihatkan bahwa petani tidak secara intensif menggunakan TIK. Hal ini berhubungan dengan terbatasnya pelatihan dan fasilitas tentang TIK untuk petani. Hal ini terdapat korelasi positif yang nyata antara partisipasi petani terhadap program agropolitan dengan tingkat pemanfaatan TIK. Diperlukan pelatihan TIK untuk usaha tani yang diikuti oleh kebutuhan fasilitas yang memadai dalam memperkuat pengetahuan dan keterampilan dalam TIK.
\end{abstract}

Kata kunci: mendukung agribisnis, terbatasnya pelatihan, terbatasnya fasilitas

\section{PENDAHULUAN}

Program Pengembangan Kawasan Agropolitan dari Dinas Pertanian Jawa Timur bertujuan memfasilitasi pengembangan dan pemantapan kawasan agropolitan berbasis komoditas unggulan lokal yang dikembangkan melalui mata rantai agrobisnis hulu, on farm (budi daya), hilir (agroindustri), dan usaha jasa pendukungnya yang kuat dan terpadu.
Kabupaten Bojonegoro mempunyai potensi hortikultura yang unggul yaitu Belimbing, Salak, dan Bawang Merah. Belimbing merupakan salah satu produk hortikultura yang spesifik dihasilkan di Kecamatan Kalitidu khususnya Desa Ngringinrejo dan Mojo. Belimbing sudah dibudidayakan pada areal perkebunan khusus sehingga lebih berpotensi untuk dikembangkan menjadi kawasan wisata baru dengan design Agrowisata. 
Sesuai dengan visi Kabupaten Bojonegoro tahun 2009-2013 yaitu kebangkitan menuju Bojonegoro yang sejahtera, madani dan berdaya saing. (Perda No. 13 Tahun 2008). Didukung oleh penetapan kawasan Agropolitan berdasarkan keputusan Bupati Bojonegoro No. 188/183A/KEP/412.12/2008 serta penetapan lokasi kawasan Agropolitan sesuai keputusan Gubernur No. 520/8821/202.2/2010. Pemerintah Kabupaten Bojonegoro menetapkan 3 kecamatan sebagai wilayah Agropolitan di Bojonegoro yaitu Kapas, Dander dan Kalitidu (KADEKA).

Selain mengembangkan keunggulan lokal program Agropolitan juga dapat didukung oleh perkembangan teknologi informasi dan komunikasi yang sangat pesat dan perannya dalam kehidupan sehari-hari dapat dirasakan dalam berbagai bidang kegiatan kehidupan manusia, termasuk pada bidang pertanian. Pembangunan pertanian dan perdesaan menyinergikan aplikasi teknologi informasi dan komunikasi dengan kegiatan komunikasi inovasi pertanian akan membuka peluang yang seluasluasnya dan meningkatkan akses petani terhadap informasi inovasi pertanian yang dibutuhkannya untuk meningkatkan kualitas dan memperkuat posisi dalam menjalankan usahatani.

Berkembang pesatnya teknologi informasi dan komunikasi tidak sejalan dengan kemampuan dan partisipasi petani dalam kegiatan pertanian. Partisipasi merupakan faktor penentu sekaligus sebagai indikator keberhasilan pembangunan. Seberapa kerasnya usaha pemerintah membangun, jika tidak melibatkan serta menumbuhkan partisipasi serta tidak didukung oleh petani, maka tingkat keberhasilan pembangunan dan keberlanjutan program pembangunan akan berbeda dengan kondisi jika petani ikut berpartisipasi. Hal ini terlihat dari hasil penelitian yang telah dilakukan oleh Triani (2011) yang menyatakan bahwa petani dalam pemanfaatan sumber informasi relatif rendah sekitar 38,1\% hanya mendapatkan informasi dari petugas lapang saja dan tidak memanfaatkan sumber informasi lain seperti media cetak, elektronik atau tokoh masyarakat, sedangkan partisipasi petani dalam menyebarkan inovasi tergolong tinggi yaitu 52,38\%. Memanfaatkan teknologi informasi yang tersedia, petani dapat memutus hubungan dengan tengkulak yang sering memberikan harga jauh di bawah harga pasar. Informasi pemasaran, peluang pasar dan harga pasar input maupun output pertanian sangat penting untuk efisiensi produksi secara ekonomi sebagai upaya meningkatkan daya saing.

Desa Ngringinrejo merupakan salah satu desa di Kecamatan Kalitidu Kabupaten Bojonegoro yang lokasinya merupakan tempat Agropolitan belimbing yang baru saja diresmikan oleh Pemerintah Bojonegoro. Desa yang memiliki potensi Agropolitan dengan berbasis teknologi informasi (internet) memberikan daya tarik bagi peneliti untuk mengetahui dan menganalisis lebih lanjut terkait tingkat partisipasi petani belimbing dalam pemanfaatan teknologi informasi dan komunikasi. Partisipasi petani yang telah disebutkan diatas menjadi indikator untuk mengukur keberhasilan rencana pemerintah yang bertujuan untuk membuat desa mandiri dengan mengandalkan potensi yang dimiliki wilayah. Oleh karena itu, diperlukan penelitian untuk menganalisis "keterkaitan partisipasi petani dalam pemanfaatan teknologi informasi dan komunikasi pada Program Agropolitan Belimbing di Bojonegoro?”

Teknologi informasi dan komunikasi belum dapat dimanfaatkan oleh petani dalam mendukung kinerja agribisnis. Hal ini terlihat dari banyaknya aspek yang disebabkan dari dalam diri dan dari lingkungan sekitar petani sehingga perlu dianalisis faktor faktor apa saja yang berhubungan dengan keterlibatan petani dalam memanfaatkan sarana dan prasarana yang telah disediakan untuk mendukung kegiatan usahatani serta apakah partisipasi petani pada program Agropolitan sudah terwujud ?

Secara rinci pertanyaan penelitian meliputi :

1. Bagaimana hubungan karakteristik diri dan sosial petani (umur, lama pendidikan, jenis kelamin, kepemilikan sarana, motivasi, tingkat kekosmopolitan dan keterlibatan petani dalam kelompok) dengan tingkat partisipasi petani pada program Agropolitan di Desa Ngringinrejo ?

2. Bagaimana hubungan karakteristik usahatani (luas penguasaan lahan dan kepemilikan modal) dengan tingkat partisipasi petani pada program Agropolitan di Desa Ngringinrejo ?

3. Bagaimana hubungan tingkat partisipasi dengan tingkat pemanfaatan teknologi informasi dan komunikasi petani 
(pengetahuan, penerimaan dan respon serta penerapan) pada program Agropolitan di Desa Ngringinrejo ?

\section{PENDEKATAN TEORITIS}

\section{Agropolitan}

Agropolitan berdasarkan Undang-Undang Nomor 26 Tahun 2007 pasal 1 ayat 24 tentang Penataan Ruang, kawasan agropolitan adalah kawasan yang terdiri dari satu atau lebih pusat kegiatan pada wilayah pedesaan sebagai sistem produksi pertanian dan pengelolaan sumber daya alam tertentu yang ditunjukkan oleh adanya keterkaitan fungsional dan hirarki keruangan satuan sistem permukiman dan sistem agribisnis. Pengembangan Kawasan Agropolitan (PKA) pada prinsipnya bukan merupakan kegiatan yang bersifat exclusive tetapi lebih bersifat complement terhadap 3 (tiga) agenda prioritas pembangunan di Jawa Timur, tahun 2009 2014, yaitu meningkatkan percepatan dan pemerataan pertumbuhan ekonomi yang berkualitas dan berkelanjutan, terutama melalui pengembangan agroindustri/ agrobisnis, serta pembangunan dan perbaikan infrastruktur terutama pertanian di perdesaan, memperluas lapangan kerja, meningkatkan efektifitas penanggulangan kemiskinan, memberdayakan ekonomi rakyat, terutama wong cilik dan meningkatkan kesejahteraan rakyat dan memelihara kualitas dan fungsi lingkungan hidup serta meningkatkan perubahan pengelolaan sumber daya alam dan penataan ruang (http://agropolitan-jatim.net.,2011).

\section{Karakteristik Diri dan Sosial Petani}

Faktor sosial ekonomi yang dipelajari dalam penelitian ini dimasukkan dalam variabel karakteristik diri dan sosial yang terdiri atas umur, pendidikan, kepemilikan sarana teknologi informasi dan komunikasi, lama menggunakan sarana teknologi informasi, dan luas penguasaan lahan.

Dua indikator yang dapat menunjukkan karakteristik individu yang berkaitan dengan interaksi dengan lingkungan sosial adalah tingkat kekosmopolitan dan keterlibatannya dalam suatu kegiatan kelompok. Tingkat kekosmopolitan adalah keterbukaan petani terhadap informasi melalui hubungan mereka dengan berbagai sumber informasi yang dibutuhkan. Menurut Mosher (1978) dalam Mulyandari (2011), keterbukaan seseorang berhubungan dengan penerimaan perubahanperubahan seseorang untuk meningkatkan kualitas kegiatan usahatani mereka. Tingkat kekosmopolitan dicirikan diantaranya dengan aktivitasnya ke luar sistem sosial, misalnya pergi ke luar sistem sosial (ke luar desa), berinteraksi dengan pihak luar sistem sosial (tamu), atau kontak dengan lembaga penelitian, keterdedahan terhadap teknologi informasi dan komunikasi, baik dalam bentuk tercetak maupun elektronik.

\section{Pemanfaatan Teknologi Informasi dan Komunikasi}

Kemampuan atau kecakapan mengetahui, mengerti, menggunakan, dan menganalisis sesuatu yang dipelajari, kemampuan mengembangkan kreasi baru dan menilai setelah mempelajari sesuatu adalah termasuk dalam unsur perilaku yang berhubungan dengan mengingat suatu materi (Hickerson dan Midletonm 1975) dan kemampuan mengembangkan intelegensia. Unsur-unsur perilaku ini dapat dimasukkan dalam golongan asek perilaku pengetahuan (knowledge behavior). Unsur pengetahuan terdiri dari knowledge (pengetahuan), comprehension (pemahaman), application (aplikasi), analysis (analisis), syntesis (syntesis) dan evaluation (evaluasi).

Unsur selanjutnya adalah afektif (sikap mental). Sikap berhubungan dengan latar belakang dan karakteristik individu yang bersangkutan. Lima kategori diurutkan mulai dari perilaku yang sederhana hingga yang paling kompleks.

- Receiving yaitu kemampuan untuk menunjukkan atensi dan penghargaan terhadap orang lain.

- Responding yaitu kemampuan berpartsipasi aktif dalam pembelajaran dan selalu termotivasi untuk segera bereaksi dan mengambil tindakan atas suatu kejadian.

- Valuing yaitu kemampuan menunjukkan nilai yang dianut untuk membedakan mana yang baik dan kurang baik terhadap suatu obyek dan nilai tersebut diekspresikan dalam perilaku. 
- Organizing yaitu kemampuan membentuk sistem nilai dan budaya organisasi dengan mengharmonisasikan perbedaan nilai.

- Characteristic by value yaitu kemampuan mengendalikan perilaku berdasarkan nilai yang dianut dan memperbaiki hubungan intrapersonal,interpersonal dan sosial.

Winkel (1989) mengemukakan ranah tujuan instruksional di bidang psikomotor ada tujuh yaitu: persepsi, kesiapan, gerakan yang terbimbing, gerakan yang terbiasa, gerakan yang kompleks, penyesuaian pola gerakan, dan kreativitas.

\section{Partisipasi}

Partisipasi masyarakat menurut Soemarto (2009) adalah proses ketika warga sebagai individu maupun kelompok sosial dan organisasi, mengambil peran serta ikut mempengaruhi proses perencanaan, pelaksanaan, dan pemantauan kebijakan yang langsung mempengaruhi kehidupan mereka. Partisipasi tidak hanya bagaimana petani bisa ikut serta dalam penyuluhan, tetapi partisipasi adalah bagaimana agar mereka dapat turut serta dalam merancang kegiatan dan memiliki kesempatan untuk mempengaruhi keputusan dalam perencanaan dan pelaksanaan kegiatan. Cohen dan Uphoff (1980) menyatakan bahwa partisipasi yang diharapkan dari masyarakat dalam kegiatan pembangunan adalah partisipasi dalam pengambilan keputusan pada perencanaan kegiatan, pelaksanaan, memperoleh hasil dan evaluasi kegiatan.

\section{Kerangka Pemikiran}

Program Pengembangan Kawasan Agropolitan dari Dinas Pertanian Jawa Timur bertujuan memfasilitasi pengembangan dan pemantapan kawasan agropolitan berbasis komoditas unggulan lokal. Sasaran pengembangan kawasan agropolitan adalah pemberdayaan masyarakat pelaku agribisnis, pengembangan komoditas unggulan pertanian, pengembangan kelembagaan petani dan penyedia jasa pertanian, serta pengembangan sarana dan prasarana penunjang.

Hal ini sejalan dengan Undang-Undang Nomor 16 tahun 2006 tentang Sistem Penyuluhan
Pertanian, Perikanan, dan Kehutanan (UU SP3K) untuk memberdayakan pelaku utama demi menciptakan lingkungan usaha yang kondusif dan meningkatkan kesadaran petani akan pentingnya informasi. Partisipasi merupakan faktor penentu sekaligus sebagai indikator keberhasilan pembangunan. Seberapa kerasnya usaha pemerintah membangun, jika tidak melibatkan serta menumbuhkan partisipasi serta tidak didukung oleh petani, maka tingkat keberhasilan pembangunan dan keberlanjutan program pembangunan akan berbeda dengan kondisi jika petani ikut berpartisipasi.

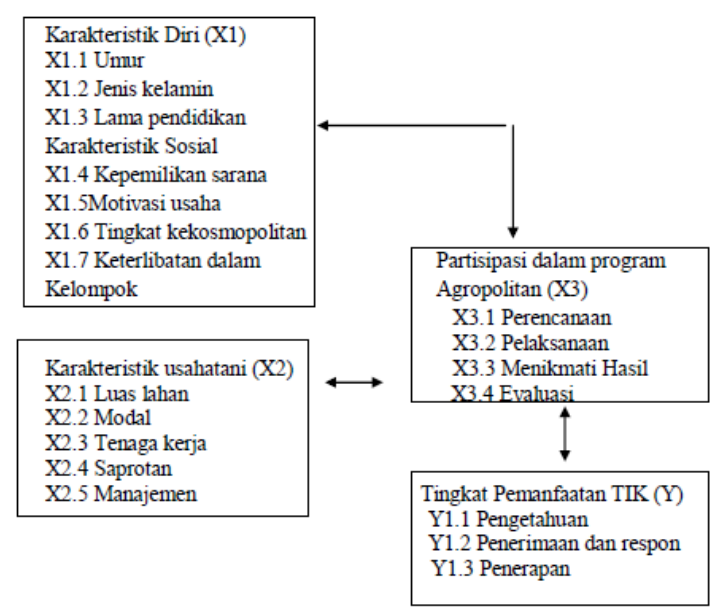

Gambar 1 Kerangka penelitian

\section{Hipotesis Penelitian}

1. Diduga terdapat hubungan antara karakteristik diri dan sosial petani dengan tingkat partisipasi.

2. Diduga terdapat hubungan antara karakteristik usahatani dengan tingkat partisipasi.

3. Diduga terdapat hubungan antara tingkat partisipasi dengan tingkat pemanfaatan TIK.

\section{METODE PENELITIAN}

Pendekatan penelitian yang dilakukan adalah pendekatan kombinasi kuantitatif dan pendekatan kualitatif. Pengambilan data dilakukan melalui dua tahap. Tahap pertama adalah pengambilan data melalui kuesioner yang dibagikan kepada responden dan tahap kedua dengan indeep interview pada informan. Penentuan responden dipilih menggunakan 
rumus Slovin dengan populasi petani sebanyak 104 orang. Sehingga responden yang didapatkan yaitu 50 orang.

Penelitian dilakukan di Desa Ngringinrejo, Kecamatan Kalitidu, Kabupaten Bojonegoro. Data yang dikumpulkan adalah data primer dan data sekunder. Data primer diperoleh melalui pengamatan langsung di lapangan dan juga melalui wawancara terstruktur dengan para responden yang telah dipilih, sedangkan data sekunder diperoleh dari berbagai literatur dan sumber pustaka yang dapat digunakan untuk berbagai konsep dan teori yang berkaitan dengan masalah yang diteliti.

Data yang diperoleh di lapangan selanjutnya diolah melalui proses pengolahan data. Proses pengolahan data ini meliputi proses pembuatan kode, pemberian skor, dan memasukkan data (entry) ke dalam Microsoft Excel 2007 dan diolah menurut statistik deskriptif dan inferensial. Tabulasi Silang digunakan untuk menyajikan data tentang karakteristik individu, karakteristik usahatani, tingkat partisipasi dan tingkat pemanfaatan TIK. Uji Korelasi Rank Spearman dilakukan untuk menganalisis hubungan antara tingkat partisipasi petani dalam pemanfaatan TIK pada Program Agripolitan. Analisis data secara kualitatif digunakan untuk memaknai hasil olahan data kuantitatif.

\section{HASIL DAN PEMBAHASAN}

\section{Gambaran Umum Wilayah Penelitian}

Desa Nginginrejo merupakan salah satu desa yang berada di Kecamatan Kalitidu, Kabupaten Bojonegoro Provinsi Jawa Timur. Secara geografis Desa Ngiringinrejo memiliki luas wilayah sebesar $166.065 \mathrm{Ha}$ dengan kondisi desa digunakan untuk perkebunan perorangan berupa kebun belimbing (Averhoa carambola L.) seluas $20.4 \mathrm{Ha}$ dan sawah irigasi seluas $80.3 \mathrm{Ha}$. Selain itu diperuntukkan sebagai lahan pekarangan $40.3 \mathrm{Ha}$, luas ladang $39.5 \mathrm{Ha}$, luas pemakaman $1.7 \mathrm{Ha}$, luas prasarana umum lainnya sebesar 1.3 Ha. Adapun batas-batas geografisnya: sebelah utara adalah Desa Mojo, sebelah selatan adalah Desa Leran, sebelah barat adalah Desa Pungpungan, dan sebelah timur adalah Desa Padang.
Populasi Desa Ngringinrejo pada tahun 2015 sejumlah 1971 jiwa yang terdiri dari laki-laki sebanyak 990 jiwa dan perempuan sebanyak 981 jiwa. Penduduk tersebut tersebar di 3 dusun, yakni Dusun Mejayan yang terdiri dari 5 RT dan $2 \mathrm{RW}$, Dusun Ngringin yang terdiri dari 4 RT dan 2 RW, dan Dusun Margorejo yang terdiri dari 2 RT dan 1 RW. Berdasarkan pendidikan, dapat dikatakan bahwa penduduk desa ini memiliki tingkat pendidikan yang rendah karena masih banyaknya proporsi penduduk yang hanya tamatan $\mathrm{SD} /$ sederajat.

Kondisi wilayah di desa Ngringinrejo memang sangat mendukung untuk mencari nafkah di bidang swasta sebelum akhirnya dengan diresmikannya Agropolitan belimbing. Saat ini mata pencaharian penduduk mulai beralih menjadi petani di tanahnya sendiri yang berada di kawasan Agropolitan belimbing.

\section{Karakteristik diri dan sosial petani}

Karakteristik diri dan sosial merupakan ciri seorang petani yang membedakan dirinya dengan orang lain dalam berinteraksi dengan lingkungan sekitarnya. Umur responden berkisar antara 15-64 tahun yang termasuk pada kategori produktif. Kisaran umur yang telah ditentukan berdasarkan kategori pemerintah (BPS 2010). Umur seorang petani sangat menentukan keterkaitannya dalam hal memanfaatkan teknologi informasi dan komunikasi untuk mendukung adanya program Agropolitan yang berada di Desa Ngringinrejo. Berikut disajikan pada Tabel 1 mengenai karakteristik diri dan sosial petani di Desa Ngringinrejo.

Lama pendidikan yang telah ditempuh berupa tahun sukses pendidikan formal seorang petani. Lama pendidikan petani di kawasan Agropolitan belimbing sebanyak $44 \%$ petani memperoleh pendidikan selama 7-12 tahun (SMP-SMA), lalu $32 \%$ petani memperoleh pendidikan selama 0-6 tahun (SD) dan sisanya yaitu $24 \%$ telah memperoleh pendidikan lebih dari 12 tahun (Perguruan Tinggi). Data ini berbeda dengan data yang diberikan oleh desa dimana mayoritas penduduk hanya lulus Sekolah Dasar. Alasan yang ditemukan adalah sebagian besar petani berhenti sekolah pada masa Sekolah Dasar dan langsung memutuskan bekerja. 
Tabel 1 Karakteristik diri dan sosial petani di Desa Ngringinrejo Tahun 2015

\begin{tabular}{|c|c|c|c|}
\hline No & $\begin{array}{c}\text { Unsur Karakteristik Diri } \\
\text { dan Sosial Petani }\end{array}$ & $\begin{array}{l}\text { Jumlah } \\
\text { (orang) }\end{array}$ & $\begin{array}{l}\text { Persentase } \\
(\%)\end{array}$ \\
\hline \multirow[t]{2}{*}{1} & $\begin{array}{l}\text { Umur (tahun) } \\
\text { a.Poduktif } \\
(15-64) \\
\text { b.Non Produktif } \\
(<15 \text { dan }>64) \\
\end{array}$ & $\begin{array}{l}47 \\
3\end{array}$ & $\begin{array}{l}94 \\
6\end{array}$ \\
\hline & Total & 50 & 100 \\
\hline \multirow[t]{2}{*}{2} & $\begin{array}{l}\text { Lama Pendidikan } \\
\text { a.Rendah (0-6 tahun) } \\
\text { b.Sedang ( } 7-12 \text { tahun }) \\
\text { c.Tinggi }(>12 \text { tahun })\end{array}$ & $\begin{array}{l}16 \\
22 \\
12\end{array}$ & $\begin{array}{l}32 \\
44 \\
24\end{array}$ \\
\hline & Total & 50 & 100 \\
\hline \multirow[t]{2}{*}{3} & $\begin{array}{l}\text { Jenis Kelamin } \\
\text { a.laki-laki } \\
\text { b.Perempuan }\end{array}$ & $\begin{array}{l}32 \\
18\end{array}$ & $\begin{array}{l}64 \\
36\end{array}$ \\
\hline & Total & 50 & 100 \\
\hline \multirow[t]{2}{*}{4} & $\begin{array}{l}\text { Kepemilikan Sarana } \\
\text { Teknologi Informasi } \\
\text { a.Sedikit } \\
\text { (hanya TV dan HP) } \\
\text { b.Sedang } \\
\text { (TV, HP, Smarthphone) } \\
\text { c.Banyak } \\
\text { (> 3 Sarana) }\end{array}$ & $\begin{array}{l}33 \\
12 \\
5\end{array}$ & $\begin{array}{l}66 \\
24 \\
10\end{array}$ \\
\hline & Total & 50 & 100 \\
\hline \multirow[t]{2}{*}{5} & $\begin{array}{l}\text { Motivasi } \\
\text { a.Rendah (skor 9-20) } \\
\text { b. Sedang (skor 21-32) } \\
\text { c. Tinggi (skor 33-45) }\end{array}$ & $\begin{array}{l}13 \\
16 \\
21\end{array}$ & $\begin{array}{l}26 \\
32 \\
42\end{array}$ \\
\hline & Total & 50 & 100 \\
\hline \multirow[t]{2}{*}{6} & $\begin{array}{l}\text { Tingkat Kekosmopolitan } \\
\text { a.Rendah }(\text { skor }<12) \\
\text { b.Sedang (skor } 12) \\
\text { c.Tinggi }(\text { skor }>12)\end{array}$ & $\begin{array}{l}14 \\
11 \\
25\end{array}$ & $\begin{array}{l}28 \\
22 \\
50\end{array}$ \\
\hline & Total & 50 & 100 \\
\hline \multirow[t]{2}{*}{7} & $\begin{array}{l}\text { Keterlibatan Petani dalam } \\
\text { Kelompok } \\
\text { a.Tidak Aktif } \\
\text { b. Aktif }\end{array}$ & $\begin{array}{l}13 \\
37\end{array}$ & $\begin{array}{l}26 \\
74\end{array}$ \\
\hline & Total & 50 & 100 \\
\hline
\end{tabular}

Petani yang berjenis kelamin laki-laki lebih mendominasi dalam menggunakan sarana dan prasarana daripada petani berjenis kelamin perempuan. Petani sudah lama menggunakan sarana teknologi informasi dan komunikasi yaitu dengan memiliki TV dan Handphone (HP) biasa. Persebaran kepemilikan sarana teknologi informasi sebanyak $66 \%$ petani memiliki sarana hanya handphone dan TV, $24 \%$ petani memiliki sarana handphone, smart phone dan TV sedangkan sisanya yaitu $10 \%$ memiliki lebih dari tiga sarana informasi yaitu handphone, smartphone, TV dan Komputer. Hal ini karena sebagian besar petani hanya menggunakan HP saja untuk berkomunikasi (sms dan telp).
Tingkat motivasi petani tinggi yaitu untuk memenuhi kebutuhan hidup dan menjalin kerjasama dengan pihak luar untuk mempermudah promosi dan meningkatkan penjualan. Tingkat kekosmopolitan petani tinggi sehingga interaksi dapat terjadi baik dengan pihak lain di luar sistem sosialnya maupun di dalam sistem sosialnya. Aktivitas ke luar sistem sosial, seperti pergi ke luar sistem sosial (ke luar desa), berinteraksi dengan pihak luar sistem sosial (tamu), atau kontak dengan lembaga penelitian, keterdedahan terhadap teknologi informasi dan komunikasi baik.

Persebaran tingkat kekosmopolitan petani tinggi yaitu berada sebanyak $64 \%$. Hal ini dibuktikan dengan seringnya petani keluar masuk desa dalam sebulan, dan juga sering menerima tamu untuk membahas mengenai pemasaran dan pemesanan produk terutama buah belimbing. Petani juga aktif mencari informasi baik pada media, internet bahkan penyuluh. Keterlibatan petani dalam kelompok tergolong aktif dalam kelompok tani maupun kelompok sadar wisata.

\section{Partisipasi Petani}

Tipologi tangga partisipasi Arnstein (1969) yaitu non-participation (rendah), degrees of tokenism (sedang), degrees of citizen contro (tinggi). Berikut disajikan tingkat partisipasi petani pada setiap tahapan pada Gambar 2.

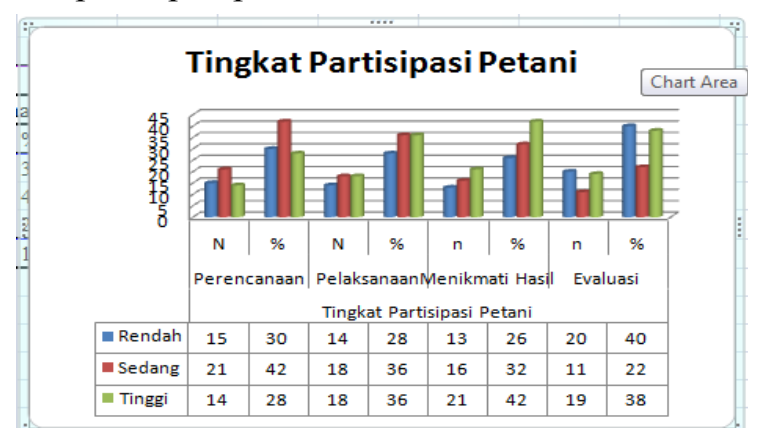

Gambar 2 Tingkat partisipasi petani

Berdasarkan Gambar 2, maka dapat diperoleh gambaran bahwa tingkat partisipasi petani pada tahap perencanaan sebesar $42 \%$ termasuk kategori sedang. Hal ini karena tidak semua petani ikut dalam kegiatan perencanaan hanya beberapa orang saja yang menyusun perencanaan pemerintah dengan beberapa aparat desa dan penyuluh. 
Tahap pelaksanaan petani sebesar 36\% berjumlah sama pada kategori sedang dan tinggi. Hal ini karena setiap dilakukan kegiatan rutin hampir 50\% yang ikut menghadirinya. Pada tahap menikmati hasil sebesar $42 \%$ petani memanfaatkan teknologi informasi dan komunikasi dengan tujuan untuk pengetahuan, berbagi informasi dan hiburan. Selain itu juga beberapa petani dapat mengaplikasikan ilmu dan informasi yang mereka dapatkan dari setiap kegiatan yang bersumber dari media, bahkan lingkungan luar. Tahap evaluasi menunjukkan hasil nilai tertinggi sebesar $40 \%$. Pada tahap evaluasi tingkat partisipasi petani tergolong rendah karena hanya sedikit petani yang menyampaikan bagaimana hasil yang mereka telah capai setelah tahap menikmati hasil pada pertemuan selanjutnya.

\section{Karakteristik Usahatani}

Karakteristik usahatani terdiri dari luas penguasaan lahan petani tergolong sedang, ketersediaan modal rendah yaitu hanya pada bidang produksi. Berikut disajikan karakteristik usahatani luas lahan, ketersediaan modal dan lama berusahatani berdasarkan jumlah dan persentase pada Gambar 3.

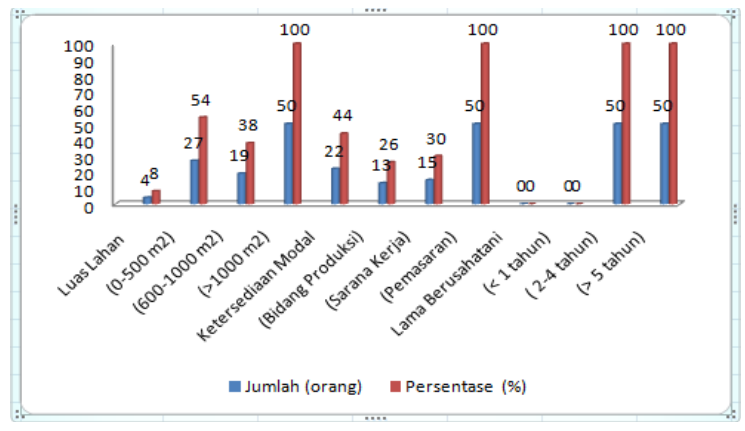

Gambar 3 Karakteristik usahatani Desa Ngringinrejo Tahun 2015

Pada Gambar 3, maka dapat dilihat penguasaan luas lahan petani di Desa Ngringinrejo adalah berada pada tingkat sedang yaitu seluas 600$1000 \mathrm{~m}^{2}$, Sebagian besar petani memiliki lahan di kebun belimbing hasil dari warisan orang tua. Selain warisan juga status kepemilikan lahan di kebun belimbing juga sebagian besar milik pribadi namun ada beberapa yang merupakan milik bengkok (sewa). Berdasarkan data yang telah didapat, modal yang dimiliki petani mayoritas untuk membangun sarana kerja dan untuk mendukung fasilitas demi meningkatkan daya saing produknya. Persebaran modal petani berada pada sektor bidang produksi yaitu sebanyak 44\%. Petani di kawasan Agropolitan belimbing pada umumnya memilih untuk menempatkan modal mereka pada sektor bidang produksi untuk memaksimalkan hasil produksi demi meningkatkan daya saing dan pendapatan. Mereka mendapatkan modal dari penyisihan hasil kebun dan dari tabungan pribadi, mereka tidak mengandalkan bantuan ataupun pinjaman dari bank maupun koperasi.

Lama berusahatani petani di Desa Ngringinrejo tergolong lama yaitu lebih dari 5 tahun. Pengalaman berusahatani didapatkan secara turun temurun dari orang tua terdahulu bahkan ada juga pengetahuan yang didapatkan melalui internet kemudian di aplikasikan langsung pada kebun sendiri setelah berhasil kemudian pada saat ada kegiatan ilmu tersebut dibagikan kepada petani lainnya hal ini sesuai dengan model komunikasi dua tahap yang dikenal dengan two step flow model of communication (Schiffman and Kanuk 2007) dimana penyebara informasi yang disampaikan melalui media massa kepada khalayaknya tidak terjadi secara langsung (satu tahap) melainkan melalui perantara. Di kawasan Agropolitan belimbing semua petani yang memiliki lahan berperan juga sebagai penggarap. Jadi petani yang memiliki lahan dan petani itu juga yang megolah atau menggarap lahan mereka untuk menghemat pengeluaran. Petani di Desa Ngringinrejo melakukan studi banding di daerah Siwalan, kemudian membudidayakan bibit yang kemudian di tanam di kebun masing masing. Kegiatan yang dilakukan dimulai dari proses penanaman bibit kemudian penyemprotan, pembungkusan, pemupukan dan pengairan.

Penggunaan saprodi di Desa Ngringinrejo masih cenderung tergantung pada bahan - bahan kimia sintetik baik berupa pupuk maupun obat obatan. Hal ini tidak terlepas dari kebiasaan yang telah terpola pada petani. Keinginan untuk mendapatkan hasil yang maksimal membuat petani tergantung menggunakan pupuk kimia sintetik, walaupun pada saat awal musim tanam tetap menggunakan pupuk organik (pupuk kandang) yang menurut petani tidak cukup. Bila mengandalkan pupuk organik saja hasil yang 
diinginkan menjadi tidak maksimal. Padahal penggunaan pupuk dan obat-obatan kimia sintetik secara terus menerus dapat menurunkan kandungan hara tanah.

Pada umumnya penyemprotan dilakukan 2 kali dalam satu minggu atau bisa menyesuaikan sesuai kebutuhan dan keadaan lingkungan tergantung petani masing masing kebun. Untuk masalah panen raya, biasanya satu tahun bisa mencapai 3-4 kali panen raya, setiap hari pengunjung bisa memetik buah belimbing yang ada di kebun.

Selain itu penggunaan pestisida dapat mengakibatkan resiko kesehatan, menurunnya kepekaan hama, resurjensi hama, memicu terjadinya ledakan hama, terbunuhnya musuh alami hama, keracunan/ kematian hewan dan tanaman disekitarnya jika salah dalam penggunaannya (Djojosumarto, 2008). Akan tetapi penggunaan pupuk organik juga mempunyai kelemahan diantaranya yaitu diperlukan dalam jumlah yang sangat banyak untuk memenuhi kebutuhan unsur hara, hara yang dikandung bahan sejenis sangat bervariasi.

Kendala yang sering dialami adalah hama ulat bulu, lalat buah dan masalah air. Ulat bulu sering mengganggu kebun mereka ketika musim penghujan tiba maka dari itu setiap satu minggu sekali mereka melakukan penyemprotan untuk menghilangkan ulat bulu di kebun mereka. Sebenarnya penyemprotan bukan hanya untuk menghilangkan ulat bulu saja, tetapi juga untuk merangsang bunga belimbing. Untuk mengamankan buah dari hama lalat buah biasanya petani melakukan upaya membungkus buah belimbing dengan plastik sejak buah masih berumur 1 minggu dengan tujuan agar buah mereka tidak di hinggapi lalat buah.

Masalah air terkadang merepotkan para petani. Ketika musim penghujan, air terlalu banyak sehingga para petani harus membuat puritan kecil di dalam kebun. Ketika musim kemarau terkadang kekurangan air dan untuk mendapatkan air, petani mengambil air dari Sungai Bengawan Solo yang dipompa dan dialirkan ke dalam kebun mereka. Berhasil atau tidaknya hasil kebun tergantung perawatan masing masing petani. Apabila kebun diperlakukan secara baik pasti hasilnya akan baik, namun apabila diperlakukan sebaliknya maka hasil kebun tidak maksimal.
Produktivitas tanaman belimbing teus meningkat dimana puncak panen setiap bulan April dan Desember dan diperingati sebagai panen raya. Jenis yang ditanam disebut dengan Belimbing Dewo (gede lan dowo-besar dan panjang) dengan ukuran buah rata-rata 20-25 cm. Setahun, satu pohon belimbing dapat menghasilkan 80-100 kg dan satu hektar lahan ditanami sekitar 500 pohon. Selain buah yang dikonsumsi langsung, petani di Desa Ngringinrejo juga mebuat produk olahan dari buah belimbing seperti sirup belimbing, keripik belimbing, kerupuk belimbing, selai belimbing, dodol belimbing, dan sari buah belimbing. Produk olahan tersebut dijual dengan berbagai macam harga mulai dari Rp 7000,00 hingga Rp 40.000,00. Produk olahan tersebut tidak selalu tersedia karena proses pembuatan yang tidak menggunakan bahan pengawet maka harus memesan terlebih dahulu jika ingin membeli produk olahan belimbing ini.

Pendapatan ketika hari libur bisa berkali lipat bahkan ketika hari hari tertentu bisa mencapai Rp 5.000.000,00- Rp 6.000.000,00. Selain dijual di lapak lapak kebun. Biasanya buah belimbing diambil tengkulak dari luar kota yang sudah menjadi langganan tetap atau bisa juga melayani pesanan pesanan lokal. Pada tahun baru 2014 penghasilan mencapai Rp 72.000.000,00 per hari sampai dengan pukul 12.00 WIB. Dan pada tanggal merah petani dapat menjual sekitar $25 \mathrm{~kg}$ sehingga penghasilan yang mereka dapatkan sebesar Rp 25.875.000,00 sedangkan untuk hari biasa sehari dapat menjual sekitar $10 \mathrm{~kg}$ dengan harga yang sama yaitu Rp 5000,00 sehingga penghasilan yang mereka raih sebesar Rp 3.450.000,00. Penghasilan ini dalam tiga tahun terakhir perekonomian penduduk di Desa Ngringinrejo meningkat secara signifikan.

Hasil kebun sebagian terjual di kebun kemudian sisanya biasa diambil tengkulak dari dalam kota Bojonegoro ataupun dari luar kota yang sudah menjadi langganan tetap. Selain dijual kepada tengkulak, petani belimbing juga melayani pesanan baik di dalam ataupun luar daerah. Kebun belimbing Desa Ngringinrejo merupakan salah satu daerah tujuan wisata unggulan Kabupaten Bojonegoro. Sarana dan prasarana penunjang terus dikembangkan oleh Pemerintah Kabupaten Bojonegoro agar menjadi Desa 
Wisata dan menjadi daerah tujuan wisata domestik maupun mancanegara khususnya di bidang agrowisata. Peluang kerjasama dengan pihak - pihak lain terus ditingkatkan. Jalinan kerjasama ini yang tetap dijaga oleh petani dengan tetap konsisten memenuhi kesepakatan kesepakatan yang telah disusun bersama. Tidak jarang para wisatawan yang datang langsung memesan produk pertanian dalam jumlah yang banyak untuk kembali diperjualbelikan di daerah asal wisatawan sendiri.

Program Agropolitan dengan adanya jaringan wifi yang bisa diakses siapa saja dan kapan saja jaringan tersebut dimanfaatkan oleh penduduk Ngringinrejo yang sebagian besar adalah pemuda. Hampir setiap malam mereka selalu berkumupul di salah satu warung yang tidak jauh dari Balai Desa untuk sekedar kumpul sambil bermain internet. Manfaat bagi pengunjung atau wisatawan dengan adanya wifi di Desa Ngringinrejo adalah menjadikan para pengunjung semakin betah berada di lokasi agrowisata kebun belimbing, sehingga dengan adanya wifi membuat agrowisata kebun belimbing Desa Ngringinrejo ini mempunyai nilai lebih.

Selain efek negatif yang ditimbulkan ada juga efek positif yang dirasakan oleh penduduk sekitar dengan adanya fasilitas wifi di desa mereka. Salah satunya ada warga yang berhasil memanfaatkan internet dengan menemukan temuan temuan yang akhirnya diterapkan atau dipakai sebagian besar petani diantaranya adalah menemukan perekat bunga atau campuran bahan organik yang disemprotkan agar bunga tidak rontok, pembasmi ulat bulu dari bahan bahan organik dan lain-lain.

\section{Tingkat Pemanfaatan Teknologi Informasi dan Komunikasi}

Tingkat pemanfaatan teknologi informasi dianalisis untuk melihat sejauh mana pengetahuan, penerimaan dan respon serta penerapan petani dalam memanfaatkan fasilitas yang disediakan berupa teknologi informasi di Desa Ngringinrejo. Berikut disajikan tingkat pemanfaatan teknologi informasi dan komunikasi pada Gambar 4.

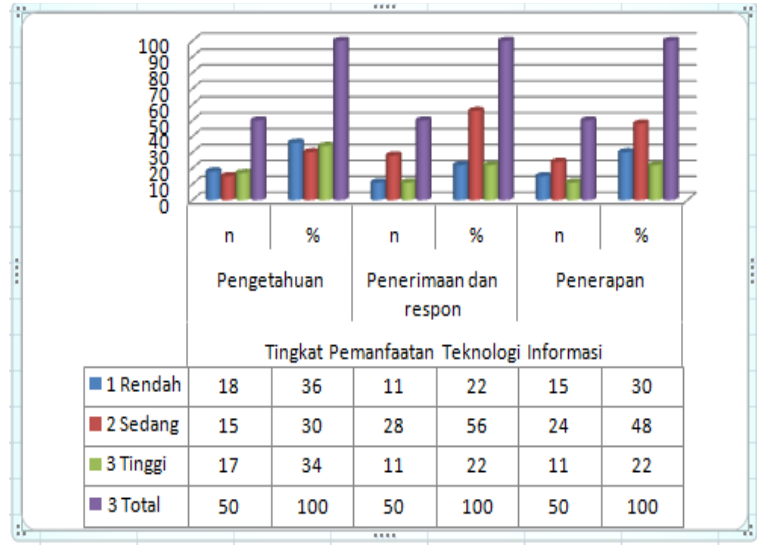

Gambar 4 Tingkat pemanfaatan teknologi informasi dan komunikasi

Pada Gambar 4, terlihat bahwa pengetahuan petani di kawasan Agropolitan belimbing Desa Ngringinrejo berada pada tingkat rendah 36\%. Namun di lapang ditemukan bahwa petani mampu menganalisis bagaimana cara mencari pemecahan masalah dengan bertukar informasi dengan yang lebih mengetahui informasi.

Kemampuan atau kecakapan mengetahui, mengerti, menggunakan dan menganalisis seseuatu yang dipelajari termasuk dalam unsur pengetahuan. Unsur pengetahuan terdiri dari knowledge (pengetahuan), comprehansion (pemahaman), analysis (analisis), syntesis (sintesis), dan evaluation (evaluasi). Pengetahuan petani pada tahap knowledge rendah, yaitu sebesar 36\%. Hal ini dilatarbelakangi oleh lama pendidikan yang dilalui petani tergolong masih rendah yaitu pada tingkat lulusan SD.

Sikap seseorang terhadap suatu obyek berbedabeda antara individu satu dan lainnya. Sikap berhubungan dengan karakteristik individu yang bersangkutan. Terdapat lima kategori yang berurutan, yaitu receiving (penerimaan), responding (respon), valuing (menilai), organizing (mengorganisasikan), characteristics by valuing (karakterisasi). Sikap petani di Desa Ngringinrejo pada kategori penerimaan dan respon petani di kawasan Agropolitan belimbing berada pada tingkat sedang yaitu $56 \%$. Hal ini terbukti dengan salah satu responden dapat menunjukkan kesukaan maupun ketidaksukaan terhadap internet. Selain itu juga responden mampu membentuk sebuah sistem nilai dan budaya untuk membentuk kelompok tani dan kelompok sadar wisata. Sama halnya dengan 
sikap petani dalam penerapan berdasarkan data yang diperoleh di lapang terlihat bahwa penerapan petani di kawasan Agropolitan belimbing Desa Ngringinrejo berada pada tingkat sedang, yaitu 48\%. Terdapat beberapa petani yang dapat mengaplikasikan komputer serta menggunakan internet sebagai media untuk mengembangkan usahatani.

Perkembangan teknologi informasi dan komunikasi seperti internet, komputer dan HP, dapat digunakan sebagai media informasi dan pengetahuan baik yang menguasai informasi dan yang tidak menguasai. Akses komunikasi digital dapat membantu meningkatkan akses terhadap peluang pendidikan, memperbesar partisipasi secara langsung, meningkatkan peluang perdagangan dan pemasaran, serta memperbesar pemberdayaan petani melalui keberlanjutan usahatani. Selain itu juga dapat memberi peluang yang lebih besar dan membuka selebar-lebarnya kesempatan bagi para pelaku pembangunan pertanian, khususnya petani untuk mengakses informasi yang dibutuhkannya. Integrasi yang efektif antara teknologi informasi dan komunikasi dalam sektor pertanian akan menuju pada pertanian berkelanjutan melalui penyiapan informasi pertanian yang tepat waktu serta relevan. Hal ini memberikan informasi yang tepat kepada petani pada proses pengambilan keputusan untuk meningkatkan produktivitasnya.

\section{Hubungan Karakteristik Diri dan Sosial dengan Tingkat Partisipasi}

Karakteristik diri dan sosial petani dengan tingkat partisipasi berhubungan positif namun tidak pada semua indikator. Baik umur dan motivasi tidak berhubungan dengan tingkat partisipasi. Umur seorang petani tidak menentukan tingkat partisipasi dalam setiap kegiatan. Semua anggota berhak mengikuti kegiatan sehingga tidak berhubungan dengan tingkat partisipasi.

Semakin lama tahun pendidikan yang ditempuh petani maka akan semakin memperkaya ilmu yang akan dibagikan dengan yang lainnya. Kepemilikan sarana memiliki hubungan positif pada tahap perencanaan dan menikmati hasil, hal ini karena dengan memiliki sarana teknologi informasi dan komunikasi akan mempermudah petani dalam merencanakan dan menikmati hasil produksi dalam kegiatan berusahatani. Tingkat kekosmopolitan petani yang menyatakan bahwa keterdedahan informasi mengenai dunia luar berhubungan positif dengan tingkat partisipasi, yaitu tahap pelaksanaan dan evaluasi. Petani dikatakan sering keluar desa dan menerima tamu serta mencari informasi secara aktif. Keterlibatan petani dalam kelompok berhubungan positif dengan tingkat partisipasi pada tahap perencanaan dan evaluasi.

\section{Hubungan Karakteristik Usahatani dengan Tingkat Partisipasi}

Karakteristik usahatani dengan tingkat partisipasi memiliki hasil hubungan yang beragam. Luas lahan dan kepemilikan modal tidak berhubungan dengan tingkat partisipasi hanya pada tahap perencanaan. Namun berhubungan dengan ketiga indikator tingkat partisipasi yaitu pelaksanaan, menikmati hasil dan evaluasi. Menjadi pemilik lahan, petani akan dapat berpartisipasi dalam kegiatan pelaksanaan dan dapat menikmati hasil dari hasil pelaksanaan kegiatan usahatani dengan didukung oleh evaluasi. Adanya lahan dan modal, petani dapat bertukar informasi bagaimana mengembangkan usahatani mereka pada tahap pelaksanaan. Selain itu juga dengan adanya program Agropolitan dan tersedianya sarana dan prasarana teknologi informasi berupa jaringan internet dan wifi dapat membantu petani di kebun belimbing untuk melakukan pemasaran pada tahap menikmati hasil.

Luas penguasaan lahan merupakan lahan yang dimiliki petani dan digunakan dalam kegiatan usahatani, sehingga tidak berhubungan dengan tahap perencanaan dalam partisipasi. Modal berusahatani adalah barang yang digunakan sebagai dasar atau bekal untuk berusahatani sehingga tidak berhubungan dengan tahap perencanaan.

\section{Hubungan Tingkat Partisipasi dengan Tingkat Pemanfaatan Teknologi Informasi dan Komunikasi}

Tingkat partisipasi dengan tingkat pemanfaatan teknologi informasi berhubungan positif. Partisipasi petani dapat dilihat dari semua tahap 
mulai dari perencanaan, pelaksanaan, menikmati hasil, dan evaluasi dalam sebuah program.

Tahap perencanaan dan menikmati hasil berhubungan positif dengan tingkat pemanfaatan (pengetahuan, penerimaan dan respon serta penerapan). Hal ini karena pengetahuan sangat penting dimiliki seorang petani agar dapat berpartisipasi dalam semua tahapan. Pada tahap pelaksanaan berhubungan positif dengan pengetahuan, penerimaan dan respon. Sebaliknya pada tahapan evaluasi hanya berhubungan positif dengan pengetahuan petani.

\section{SIMPULAN DAN SARAN}

\section{Simpulan}

Karakteristik diri dan sosial petani di Desa Ngringinrejo mayoritas berada pada umur produktif (15-64 tahun) dan tingkat motivasi dalam berusahatani tergolong tinggi. Laki-laki lebih aktif menggunakan sarana TIK daripada perempuan. Lama pendidikan petani berada diantara 7-12 tahun. Kepemilikan sarana yang dimiliki petani hanya TV dan handphone.

Hubungan karakteristik diri dan sosial petani dengan partisipasi pada Program Agropolitan, yaitu:

a. Umur dan motivasi petani tidak berhubungan dengan tingkat partisipasi dalam program agropolitan.

b. Tingkat kekosmopolitan petani berhubungan positif dengan tingkat partisipasi dalam program yaitu tahap pelaksanaan dan evaluasi.

c. Keterlibatan petani dalam kelompok cukup aktif dan berhubungan dengan partisipasi pada tahap perencanaan dan evaluasi.

d. Tingkat kepemilikan sarana TIK berhubungan positif dengan partisipasi petani pada tahap perencanaan, pemanfaatan hasil dan evaluasi.

e. Tingkat kekosmopolitan berhubungan dengan partisipasi pada tahap perencanaan, pelaksanaan, pemanfaatan hasil dan evaluasi.

Karakteristik usahatani yaitu luas penguasaan lahan petani yaitu seluas $600-1000 \mathrm{~m}^{2}$. Tingkat kepemilikan modal berada pada sektor produksi dapat berhubungan positif dengan partisipasi yaitu pada tahap pelaksanaan, menikmati hasil dan evaluasi.

Pelaksanaan Program Agropolitan di Desa Ngringinrejo cukup aktif. Tergambar dari partisipasi petani dalam tahap perencanaan yang tergolong sedang, tahap pelaksanaan dan menikmati hasil yang tergolong tinggi, serta tahap evaluasi yang tergolong rendah. Dapat dikatakan partisipasi petani pada Program Agropolitan cukup beragam.

Hubungan partisipasi petani pada Program Agropolitan dengan tingkat pemanfaatan TIK, yaitu:

a. Tahap perencanaan berhubungan dengan tingkat pemanfaatan TIK yaitu pengetahuan, penerimaan dan respon serta penerapan.

b. Tahap pelaksanaan dengan tingkat pemanfaatan yaitu pengetahuan dan penerimaan respon.

c. Tahap menikmati hasil dengan tingkat pemanfaatan teknologi informasi yaitu pengetahuan, penerimaan dan respon serta penerapan.

\section{Saran}

Merujuk kepada tujuan penelitian dan hasil penelitian serta memperhatikan faktor-faktor yang berhubungan dengan Program Agropolitan disarankan agar

1. Dinas Pertanian Kabupaten Bojonegoro perlu mengembangkan program promosi atau penyebarluasan informasi mengenai Program Agropolitan, disertai penyuluhan mengenai peningkatan kapasitas petani dan fasilitator program tersebut, terutama terkait TIK di Desa Ngringinrejo.

2. Dinas KOMINFO perlu memastikan keteraksesan dan kemanfaatan infrastruktur TIK oleh petani dan memberikan pendampingan yang relevan dalam konteks agribisnis belimbing. Pendampingan tersebut perlu diikuti oleh evaluasi dan tindaklanjut.

3. Pemerintah Daerah melalui Dinas UMKM perlu mengembangkan pasar hasil agribisnis belimbing di daerah sekitar untuk menjamin terserapnya hasil panen belimbing dan produk olahannya. 


\section{DAFTAR PUSTAKA}

[BPS] Badan Pusat Statistik. 2010. Jumlah Penduduk di Indonesia [Internet]. Diakses pada tanggal 16 September 2014. Tersedia pada: http://www.bps.go.id/tab_sub view. php?tabel $=1 \&$ id_subyek $=12$

Djojosumarto, P. 2008. Teknik Aplikasi Pestisida Pertanian. Yogyakarta (ID): Kanisius.

Heckerson Francine J dan John Middleton. 1975. Helping People Learn: A Module for Trainers. Hawai: East West Center.

Kementerian Pertanian. 2010. Program Dukungan Pengembangan Kawasan Agribisnis Hortikultura. [internet]. Diakses pada tanggal 8 Mei2015.Tersedia pada: http://hortikultura.litbang.pertanian.

go.id

Sumarto, Hetifah Sj. 2009. Inovasi, Partisipasi, dan Good Governance: 20 Prakarsa Inovatif dan Partisipatif di Indonesia. Jakarta (ID): Yayasan Obor Indonesia

Triani EN. 2011. Analisis Hubungan Karakteristik Sosial Ekonomi dengan Tingkat Adopsi Petani Dalam Meng-gunakan Pupuk Organik Pada Tanaman Jagung Hibrida (Zea mays L.) di Kabupaten Sumenep (Kasus Kelompok Tani Harapan Baru di Desa Tambaagung Tengah, Kecamatan Ambunten). [Internet]. (diunduh pada tanggal 22 Oktober).

Winkel WS. 1989. Psikologi Pengajaran. Jakarta (ID): Gramedia. 